\title{
Jenis-Jenis Tumbuhan Parasit dan Persebarannya di Institut Teknologi Bandung (ITB) Kampus Ganesha
}

\section{Parasitic Plants and Their Distributions at Institut Teknologi Bandung (ITB) Ganesha Campus}

\author{
MEIDORAEKA RIGINE TAMBUNAN ${ }^{* *}$, REZA RAIHANDHANY ${ }^{2}$ \\ ${ }^{\text {I}}$ Sosial Bisnis Indonesia (SOBI) Menara BTPN, Jenius Cocowork, $47^{\text {th }}$ Floor, CBD Mega Kuningan \\ Jakarta 12950 \\ ${ }^{2}$ Yayasan Generasi Biologi Indonesia (Genbinesia) Divisi Botani, Gresik
}

Diterima 13 April 2020/Disetujui 23 September 2020

\begin{abstract}
Parasitic plants are a group of plants that live and have a broad ecological distribution which in general attack trees, shrubs or herbs to be used as a host. Some parasitic plants attacked some plants in Institut Teknologi Bandung (ITB) Ganesha Campus, Bandung. Exploration and collection of these parasitic plants in this area are conducted. Three parasitic plants species, such as Cuscuta australis, Scurrula parasitica, and Dendrophthoe pentandra are recorded and they attack 7 other plants species in ITB Ganesha. $S$. parasitica is reported as the highest population species to parasiting 5 plants species, while $C$. australis only parasiting 3 plants species and $D$. pendantra is parasiting 4 plants.
\end{abstract}

Key words: Cuscuta, Dendrophthoe, ITB Ganesha Campus, Mapping, Parasite, Scurrula

\section{PENDAHULUAN}

Tumbuhan parasit merupakan suatu kelompok tumbuhan yang hidup dan memiliki sebaran ekologi yang cukup luas. Pada umumnya, tumbuhan parasit menyerang pohon atau perdu bahkan herba yang kemudian dijadikan inangnya. Bagian-bagian yang diserang di antaranya ranting, cabang, sampai akar. Dalam keberlangsungan hidupnya, tumbuhan parasit membentuk akar termodifikasi yang disebut haustorium (Irving and Cameron 2009). Haustorium membentuk sebuah hubungan secara morfologi maupun fisiologi terhadap tumbuhan lain yang dijadikan inang oleh tumbuhan parasit tersebut, khususnya dalam upaya memperoleh sumber nutrisi untuk kelangsungan hidupnya. Tumbuhan parasit digolongkan sebagai heterotrof karena mendapatkan sebagian atau seluruh makanannya dari organisme lain, tidak seperti kebanyakan golongan tumbuhan bersifat autotrof yang mampu berfotosintesis dan menghasilkan makanannya sendiri (Nickrent 2002).

Secara garis besar, tumbuhan parasit dibagi menjadi dua tipe berdasarkan sifat parasitiknya, yaitu hemiparasit atau parasit obligat dan holoparasit atau parasit fakultatif (Twyford 2018). Hemiparasit adalah jenis parasit yang memiliki klorofil dan mampu berfotosintesis, akan tetapi memperoleh air serta nutrisi

*Penulis korespondensi:

E-mail: mriginet@gmail.com melalui haustorium. Holoparasit hampir tidak atau tidak berklorofil sehingga tidak berfotosintesis lalu sangat tergantung pada inangnya dalam memperoleh air dan nutrisi (Heide-Jørgensen 2008). Pada jenis holoparasit, tumbuhan-tumbuhan parasit tersebut harus memiliki inang untuk tetap bertahan hidup. Di samping itu, jenis dari parasit juga dibedakan menjadi dua tipe, ada tipe parasit batang dan parasit akar. Pada tipe parasit batang tumbuhan inang, nutrisi didapatkan dari batang sedangkan tipe parasit akar mendapatkannya dari akar tumbuhan inang (Heide-Jørgensen 2008).

Sunaryo (1998) menyatakan bahwa jenisjenis tumbuhan parasit sangat tersebar dan dapat dijumpai mulai dari kawasan hutan (Rafflesia dan Balanophora), kawasan konservasi seperti Kebun Raya dan Taman Hutan Raya (Dendrophthoe, Macroselon, dan Helixanthera), area perkebunan dan pertanian (Striga dan Orobanche), daerah pemukiman penduduk, pedesaan hingga perkotaan (Cuscuta dan Scurrula). Dilihat dari sebarannya, tumbuhan parasit tidak hanya hidup menginang kepada tumbuhan liar, tetapi juga dapat menyerang sejumlah tanaman yang dibudidaya (Pitoyo 1996). Keberadaan tumbuhan parasit pada suatu daerah ditentukan oleh faktor penyebarannya, iklim, dan jenis-jenis tumbuhan inang yang sesuai untuk pertumbuhannya (Kuijt 1969).

Institut Teknologi Bandung (ITB) Kampus Ganesha terletak di Jalan Ganesha No. 10, Kelurahan Lebak Siliwangi, Kecamatan Coblong, Bandung dengan luas wilayah sebesar 28.68 ha. Sekilas, ITB Kampus 
Ganesha tidak lepas dari keberadaan tumbuhan parasit yang tumbuh dan mengingang di tumbuhan koleksi kampus. Penelitian ini bertujuan untuk mencari informasi tentang jenis tumbuhan parasit yang memarasiti tumbuhan lain di ITB Kampus Ganesha lalu memetakan persebarannya. Selain itu, hasil dari penelitian ini juga diharapkan dapat membantu usaha pemberantasan tumbuhan parasit sebagai bentuk upaya perawatan tumbuhan di ITB Kampus Ganesha.

\section{BAHAN DAN METODE}

Bahan dan alat yang digunakan dalam penelitian ini antara lain: kamera, GPS, perangkat lunak ArcMap, alat tulis, lembar pencatatan, dan buku identifikasi flora berjudul Flora of Java Volume 2 (Backer and Van den Brink 1965), Flora of China Volume 5 (Qiu and Gilbert 2003), dan Flora of China Volume 16 (RhuiCheng et al. 1995). Penelitian ini dilakukan di ITB Kampus Ganesha pada Bulan Januari 2020 dengan menggunakan metode jelajah (Rugayah et al. 2004). Seluruh wilayah ITB Kampus Ganesha yang luasnya 28.62 ha dijelajahi untuk mencari tumbuhan parasit. Setiap jenis parasit beserta tumbuhan inang yang ditemukan kemudian dicatat di lembar pengamatan, difoto, kemudian dihitung jumlah individunya, lalu ditentukan titik koordinatnya dengan menggunakan GPS untuk selanjutnya dipetakan dengan menggunakan perangkat lunak ArcMap. Peta ITB Kampus Ganesha ditampilkan di Gambar 1.

\section{HASIL}

Berdasarkan hasil penelusuran di ITB Kampus Ganesha, ditemukan tiga jenis tumbuhan parasit yang terdiri atas Cuscuta australis dari suku Convolvulaceae, lalu Scurrula parasitica, dan Dendrophthoe pentandra yang sama-sama berasal dari suku Loranthaceae. $C$. australis memarasiti tiga jenis tumbuhan inang, di antaranya Acalypha siamensis, Euphorbia milii, dan Lagerstroemia indica, lalu $S$. parasitica memarasiti lima jenis tumbuhan inang, yaitu $L$. indica, Bauhinia blakeana, Pithecellobium jiringa, Nerium oleander, dan Tabebuia argentea, kemudian $D$. pentandra memarasiti empat tumbuhan inang, antara lain $L$. indica, Codiaeum variegatum, $N$. oleander, dan $B$. blakeana. Ketiga jenis parasit tersebut ditampilkan pada Gambar 2.

Secara keseluruhan, ketiga jenis parasit ini memarasiti sebanyak delapan jenis tumbuhan inang dari lima suku. Daftar hasil dari tumbuhan parasit dan inangnya di ITB Kampus Ganesha ditampilkan pada Tabel 1.

\section{PEMBAHASAN}

Berdasarkan Tabel 1, dapat dilaporkan bahwa ketiga jenis parasit ditemukan di 18 titik pengamatan di wilayah Kampus Ganesha dengan wilayah yang dapat ditemukan ketiga jenis parasit tersebar di Gedung CAS, Gedung Oktagon, dan Laboratorium
Fisika Dasar dengan populasi gabungan ketiga jenis parasit terbanyak sebesar 9 individu pada wilayah Gedung Oktagon.

Jenis parasit yang dominan memarasiti tumbuhan inang di ITB Kampus Ganesha adalah $S$. parasitica yang ditemukan memarasiti lima jenis tumbuhan inang dan paling banyak memarasiti jenis $L$. indica sebanyak enam individu yang terletak di Gedung CAS dan pada T. argentea sebanyak lima individu yang terletak di kawasan Perpustakaan Pusat. Jenis parasit C. australis ditemukan memarasiti beberapa jenis tumbuhan inang, di antaranya Acalypha siamensis, Euphorbia milii, dan L. indica yang letaknya tersebar di berbagai tempat mulai dari kawasan Gedung CAS, Gedung Kerjasama PLN-ITB, Gedung Oktagon, Laboratorium Fisika Dasar, Laboratorium Mesin, dan Labtek III. Jenis parasit $D$. pentandra, memarasiti sebanyak empat jenis tumbuhan inang dan paling banyak ditemukan memarasiti tumbuhan $L$. indica sebanyak 10 individu yang berlokasi di sekitar Komplek Gedung Oktagon, lalu ditemukan juga sebanyak tujuh individu pada Bauhinia blakeana yang berada di sekitar Labtek XIV.

Sementara untuk jenis inang yang paling banyak terserang parasit adalah jenis $L$. indica dari suku Lythraceae. Ketiga jenis parasit ditemukan memarasiti jenis inang ini dengan jumlah terbanyak terdapat pada L. indica yang terletak di Komplek Gedung Oktagon Peta persebaran tumbuhan parasit D. pentandra, $C$. australis dan $S$. parasitica beserta tumbuhan inangnya di ITB Kampus Ganesha dapat dilihat pada Gambar 3.

\section{Deskripsi Jenis-jenis Tumbuhan Parasit di ITB}

\section{Kampus Ganesha.}

1. Cuscuta australis R.BR.

Nama Lokal : Taliputri (Indonesia)

Distribusi : Australia, Eropa, Afrika, dan

Asia (Govaerts 1999)

Habitat :Wilayah hutan maupun pertanian (Yu et al. 2011)

C. australis memiliki ciri bentuk batang yang tipis, berwarna emas-kuning, dan tidak mem-iliki daun (Backer and Van den Brink 1965; Rhui-Cheng et al. 1995). Tumbuhan ini dikategorikan ke dalam holoparasitik, karena apabila tidak memarasiti inang, maka Cuscuta spp. tidak akan bisa hidup dan menghasilkan keturunan (Furuhashi et al. 2011). Di samping itu, Cuscuta juga tergolong ke dalam tumbuhan parasit yang menyerang batang atau parasit batang. Batang dari C. australis yang membelit pada batang maupun cabang inangnya dapat melekat berkat bantuan haustorium yang masuk ke dalam batang atau cabang inangnya.

Haustorium memiliki fungsi untuk untuk menghisap nutrisi dan air dari tumbuhan inang. Haustorium dari Cuscuta spp. yang masuk ke dalam batang atau cabang inangnya akan terkoneksi dengan xylem dan floem inang (Kuijt 1969). Hal tersebut dapat terjadi karena tumbuhan parasit memiliki sistem hormon dan respons fisiologis yang sama dengan tumbuhan inangnya dan hal ini mengindikasikan bahwa tumbuhan inang tidak akan selalu dapat menggunakan strategi pertahanan yang 
Kampus Institut Teknologi Bandung

Keterangan

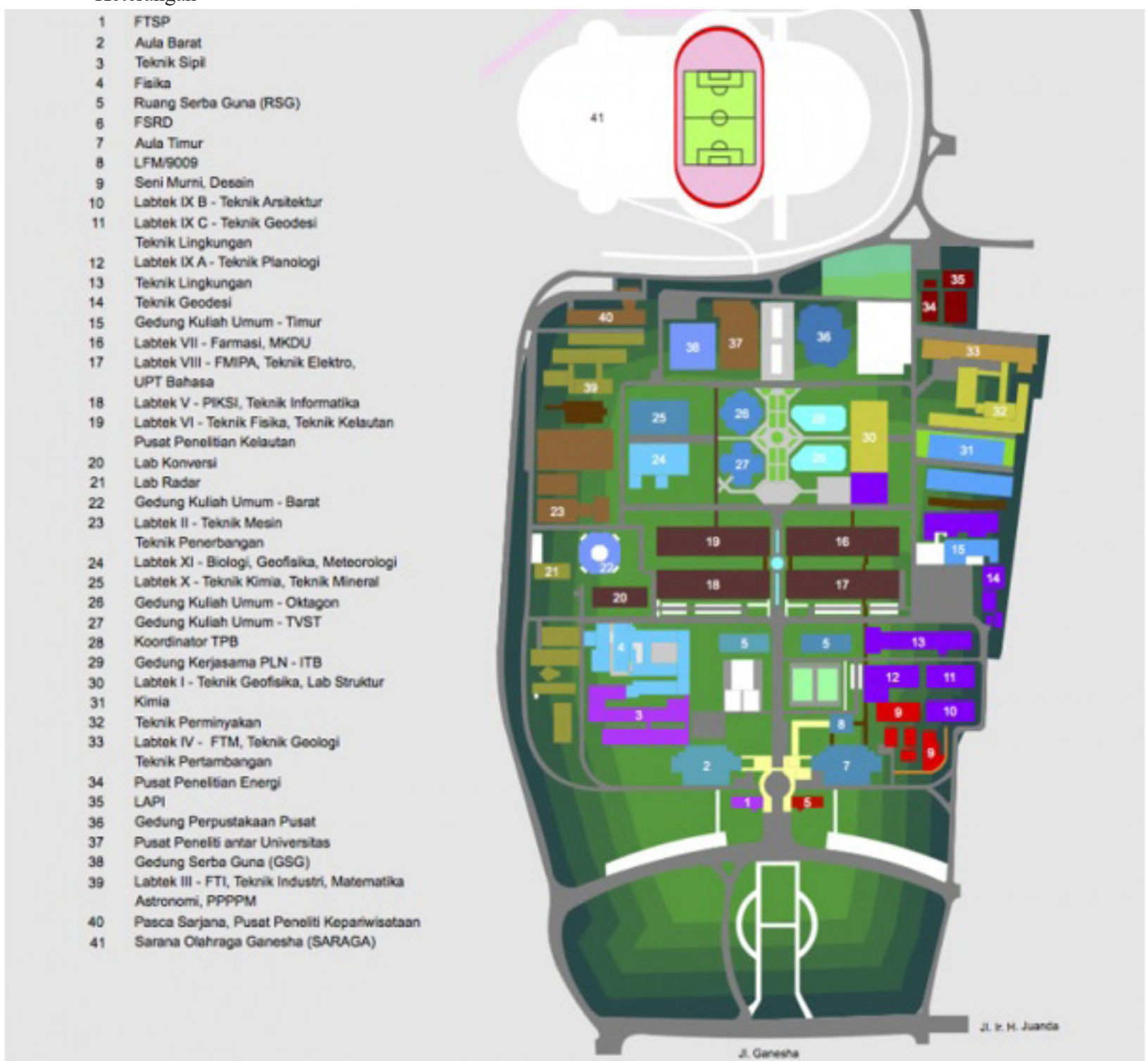

Gambar 1. Peta ITB Kampus Ganesha

sama dalam menghadapi tumbuhan parasit (Pennings and Callaway 2002). Menurut Sunaryo (2003), penyebaran tumbuhan parasit Cuscuta dapat berasal dari aktivitas manusia, seperti membawa tumbuhan siap tanam yang ternyata benih atau tanah tumbuhan tersebut sudah terkontaminasi oleh benih Custuta. Kemudian dalam penanggulangannya, berdasarkan laporan dari Li (1987) dalam Sarić-Krsmanović and Vrbničanin (2015), pengendalian C. australis dapat dilakukan dengan biokontrol menggunakan suspensi konidia dari jamur fitopatogen Colletotrichum gloeosporioides. Sunaryo (2003) menyatakan bahwa penanganan untuk parasit Cuscuta spp. dapat dilakukan dengan herbisida, pencabutan inang dari akar, hingga pembakaran. Dari ketiga cara tersebut, penggunaan herbisida menjadi cara yang paling memungkinkan untuk diterapkan di ITB Kampus Ganesha daripada pencabutan inang maupun pembakaran. Mencabut jenis inang $A$. siamensis dan $L$. indica yang sudah tumbuh dengan rimbun dan mengelompok dirasa sulit dilakukan. Di samping itu, pemangkasan pada bagianbagian cabang inang yang terkena parasit Cuscuta australis dapat juga dilakukan.

Wardini and Kusdianti (2005) mengemukakan bahwa dampak yang ditimbulkan dari parasitisme C. australis pada tumbuhan inangnya adalah pada bagian daun dan pucuk menguning serta mengering, lalu lama-kelamaan mengakibatkan terhentinya pertumbuhan inang, sebagaimana yang teramati pada A. siamensis di sekitar Laboratorium Teknik Mesin dan E. milii di Gedung Oktagon yang daunnya terlihat layu dan mengering seperti yang ditampilkan pada Gambar 4.

2. Scurrula parasitica $\mathrm{L}$.

Nama Lokal : Benalu (Indonesia)

Distribusi : Cina, Taiwan, Bangladesh, Bhutan, India, Indonesia, Malaysia, Myanmar, Nepal, Filipina, Thailand, dan Vietnam (Qiu and Gilbert 2003) 


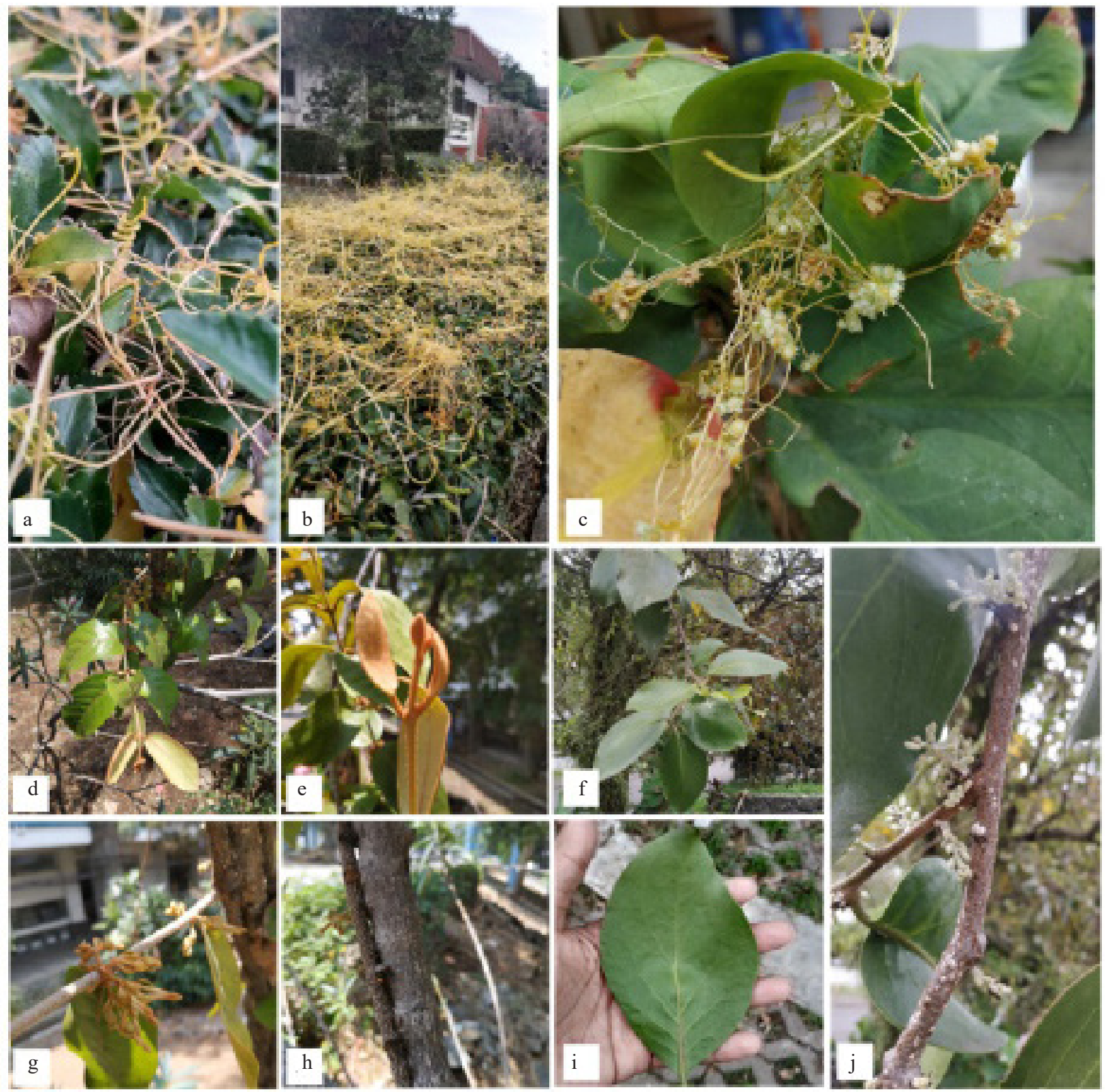

Gambar 2. (a dan b) C. asutralis, (c) perbungaan dari C. australis, (d) S. parasitica, (e) pucuk dari S. parasitica, (f) perbungaan dari S. parasitica, (g) akar hasutorium S. parasitica, (h) D. pentandra, (i) permukaan bawah daun D. pentandra, (j) perbungaan dari $D$. pentandra

Habitat

: Umum ditemukan di hutan primer dan daerah-daerah lain yang telah terganggu (Uji et al. 2007)

S. parasitica termasuk ke dalam suku Loranthaceae yang merupakan golongan hemiparasitik, melekat pada tumbuhan inang dengan menggunakan haustorium. (Uji et al. 2007). Bagian cabang atau ranting tumbuhan inang yang terserang $S$. parasitica akan mengalami infeksi, umumnya pada bagian ranting atau cabang, dan lama-kelamaan akan menyebabkan kerusakan hingga kematian (Nuthan and Vasundhara 1997; Thriveni et al. 2010). Menurut Nuthan and Vasundhara (1997), jenis tumbuhan parasit $S$. parasitica yang tumbuh dan memarasiti cabang pada inang Calliandra guildingii dan $C a$. speciosa di India dapat tumbuh hingga menembus bagian kortikal tumbuhan inang tersebut, jika dibandingkan dengan jenis tumbuhan parasit $D$. pentandra. Hal ini dapat menyebabkan pertumbuhan tumbuhan inang dan juga nilai estetikanya, sehingga jenis parasit $S$. parasitica tampak terlihat tumbuh lebih baik/subur daripada inang-inangnya.

Tumbuhan parasit merupakan salah satu spesies kunci dalam ekosistem hutan yang termasuk dalam rantai makanan dengan burung sebagai vektor penyebaran benihnya (Maarel 2005). Burung-burung dari suku Dicaedae adalah burung yang umum membantu dalam penyebaran benih tumbuhan parasit (van Leeuwen 1954). Burung dari suku Dicaedae, marga Dicaeum memiliki preferensi untuk memakan buah S. parasitica, merujuk pada penelitian Devkota and Kunwar (2006). Kemudian berdasarkan catatan dari Sholihah (2011), burung Cabai Jawa (Dicaeum trochileum) yang tergolong dalam suku Dicaeidae kerap dijumpai di kawasan ITB Kampus Ganesha. 
Tabel 1. Daftar suku dan jenis tumbuhan inang di ITB Kampus Ganesha yang terserang parasit dan jenis serta jumlah parasitnya

\begin{tabular}{|c|c|c|c|}
\hline Lokasi & Suku dan jenis inang & Jenis parasit & Jumlah Individu parasit \\
\hline \multirow[t]{2}{*}{ Basic Science Center A } & Lythraceae & & \\
\hline & Lagerstroemia indica & II & 1 \\
\hline \multirow[t]{2}{*}{ Gedung Aula Barat } & Lythraceae & & \\
\hline & Lagerstroemia indica & I & 2 \\
\hline \multirow[t]{2}{*}{ Gedung CADL } & Lythraceae & & \\
\hline & Lagerstroemia indica & I & 1 \\
\hline \multirow[t]{3}{*}{ Gedung CAS } & Euphorbiaceae & & \\
\hline & $\begin{array}{l}\text { Acalypha siamensis } \\
\text { Lythraceae }\end{array}$ & III & $\sim$ \\
\hline & Lagerstroemia indica & I, II & 3,6 \\
\hline \multirow[t]{2}{*}{ Gedung Kerjasama PLN-ITB } & $\begin{array}{l}\text { Euphorbiaceae } \\
\text { Acalypha siamensis } \\
\text { Lythraceae }\end{array}$ & III & $\sim$ \\
\hline & Lagerstroemia indica & III & $\sim$ \\
\hline \multirow[t]{2}{*}{ Gedung Kuliah Umum Timur } & $\begin{array}{l}\text { Euphorbiaceae } \\
\text { Codiaeum variegatum } \\
\text { Lythraceae }\end{array}$ & I & 1 \\
\hline & $\begin{array}{l}\text { Lagerstroemia indica } \\
\text { Bignoniaceae }\end{array}$ & I, II & 1,2 \\
\hline \multirow{4}{*}{ Gedung Oktagon } & $\begin{array}{l}\text { Tabebuia argentea } \\
\text { Euphorbiaceae }\end{array}$ & II & 1 \\
\hline & Acalypha siamensis & III & $\sim$ \\
\hline & $\begin{array}{l}\text { Euphorbia milii } \\
\text { Lythraceae }\end{array}$ & III & $\sim$ \\
\hline & Lagerstroemia indica & I, II & 10,2 \\
\hline \multirow[t]{2}{*}{ Gedung PAU } & Bignoniaceae & & \\
\hline & Tabebuia argentea & II & 2 \\
\hline Gedung Seni Rupa & $\begin{array}{l}\text { Lythraceae } \\
\quad \text { Lagerstroemia indica }\end{array}$ & II & 3 \\
\hline \multirow[t]{2}{*}{ Gedung TVST } & Lythraceae & & \\
\hline & Lagerstroemia indica & I, II & 5,1 \\
\hline \multirow[t]{3}{*}{ Laboratorium Fisika Dasar } & Euphorbiaceae & & \\
\hline & $\begin{array}{l}\text { Acalypha siamensis } \\
\text { Lythraceae }\end{array}$ & III & $\sim$ \\
\hline & Lagerstroemia indica & I, II & 5,3 \\
\hline \multirow[t]{2}{*}{ Laboratorium Mesin } & Euphorbiaceae & & \\
\hline & Acalypha siamensis & III & $\sim$ \\
\hline \multirow[t]{2}{*}{ Laboratorium Pengujian Doping } & Apocynaceae & & \\
\hline & Nerium oleander & I, II & 1,3 \\
\hline \multirow[t]{2}{*}{ Labtek III } & Euphorbiaceae & & \\
\hline & Acalypha siamensis & III & $\sim$ \\
\hline \multirow[t]{2}{*}{ Labtek VI } & Apocynaceae & & \\
\hline & Nerium oleander & II & 1 \\
\hline \multirow[t]{2}{*}{ Labtek XI } & Lythraceae & & \\
\hline & Lagerstroemia indica & I, II & 6,1 \\
\hline \multirow[t]{2}{*}{ Labtek XIV } & Fabaceae & & \\
\hline & Bauhinia blakeana & I, II & 7,1 \\
\hline \multirow[t]{3}{*}{ Perpustakaan Pusat } & Bignoniaceae & & \\
\hline & $\begin{array}{l}\text { Tabebuia argentea } \\
\text { Fabaceae }\end{array}$ & II & 5 \\
\hline & Pithecellobium jiringa & II & 2 \\
\hline
\end{tabular}

$\mathrm{I}=$ Dendrophtoe pentandra, $\mathrm{II}=$ Scurrula parasitica, $\mathrm{III}=$ Cuscuta australis, $\sim=$ untuk C. australis, jumlah individu tidak bisa dihitung

Hal ini menjadi acuan bahwa jenis tumbuhan parasit $S$. parasitica cukup banyak terdistribusi di ITB Kampus Ganesha. Berdasarkan pernyataan dari Sunaryo (2008a) pengendalian yang dapat dilakukan untuk menangani parasit Scurrula yaitu dengan melakukan pemangkasan bagian cabang/ ranting dari tumbuhan inang yang terparasiti. Dalam pengamatan, dampak kerusakan yang ditimbulkan oleh $S$. parasitica paling terlihat jelas terlihat pada tumbuhan inang Nerium oleander yang terletak di Labtek VI, ditemukan dalam keadaan daun-daunnya sudah rontok, sebagaimana ditampilkan di Gambar 5.

3. Dendrophthoe pentandra (L.) Miq.

Nama Lokal : Pasilan Cengkih, Benalu Cengkih (Indonesia), Kemladean, Benalu Cengkeh (Jawa) 
Peta ITB Kampus Ganesha

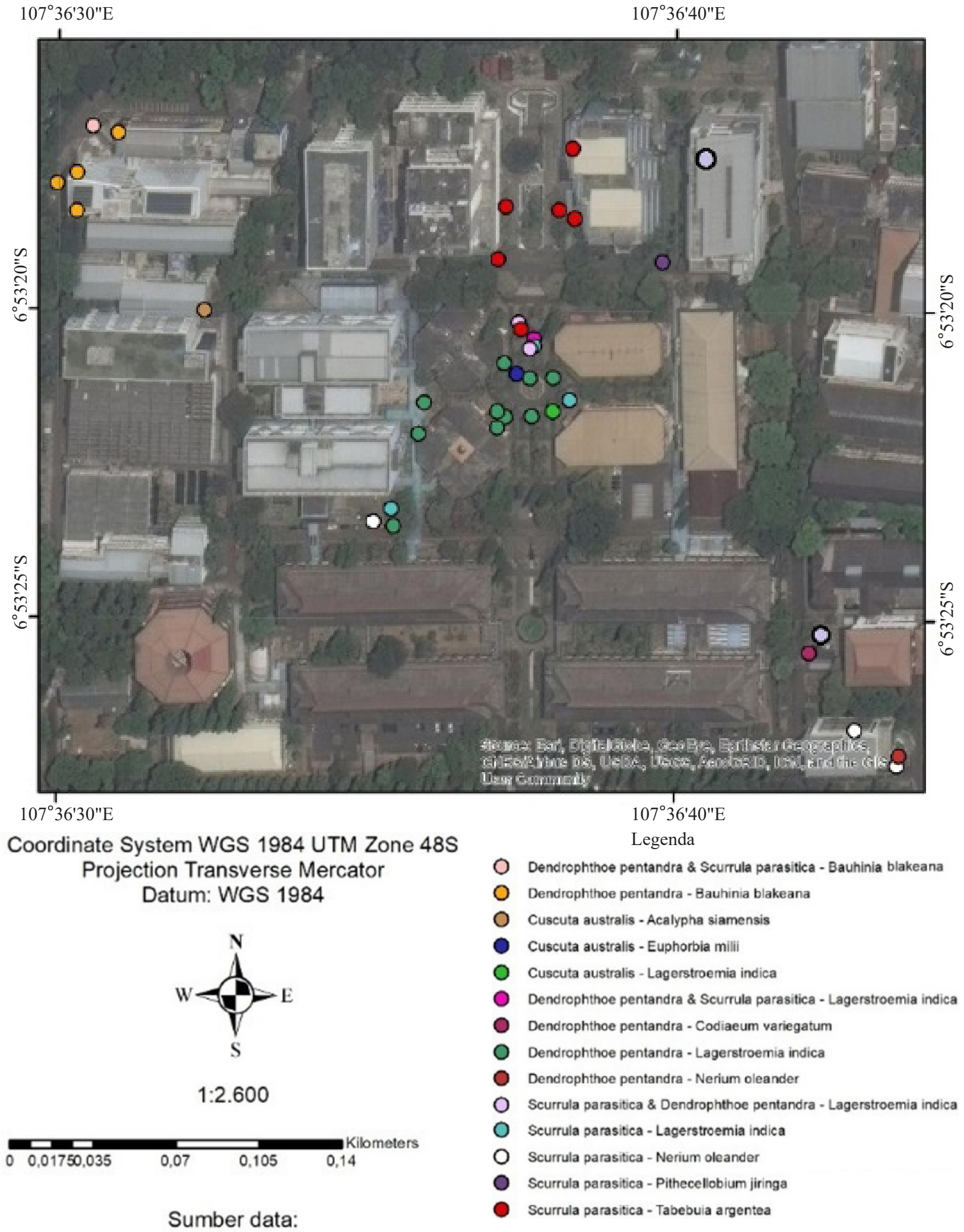

1. Hasil Survey

2. Basemap World Imagery

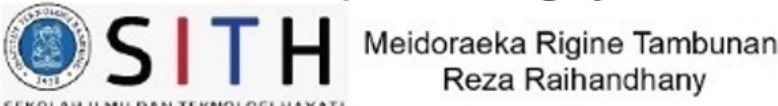

SEKOLAH ILMU DAN TEKMOLOGI HAYAII

Gambar 3. Peta persebaran tumbuhan parasit dan inang di ITB Kampus Ganesha 

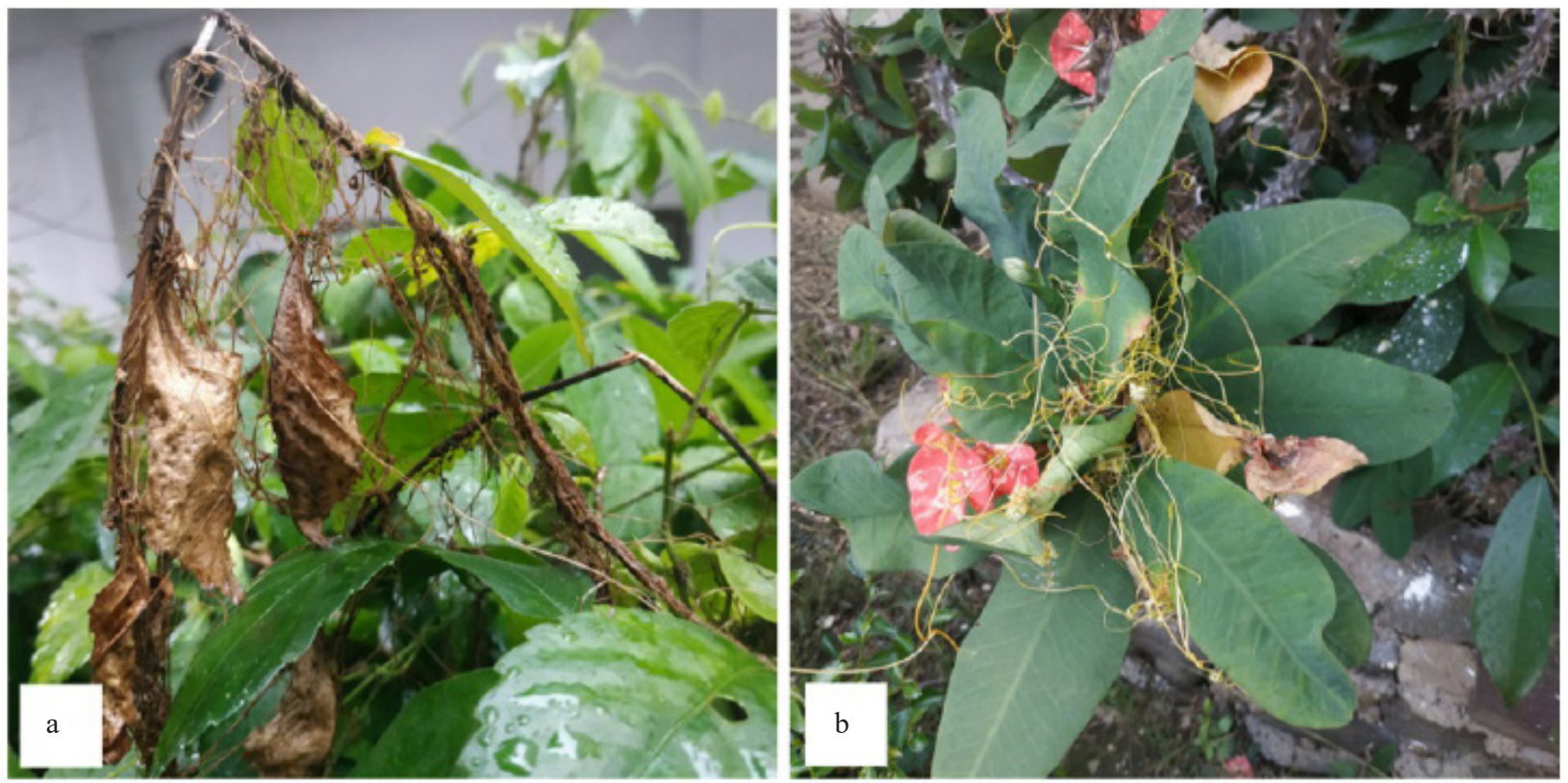

Gambar 4. C. australis memarasiti A. siamensis di sekitar laboratorium mesin (a) dan E. milii di sekitar Gedung Oktagon (b)

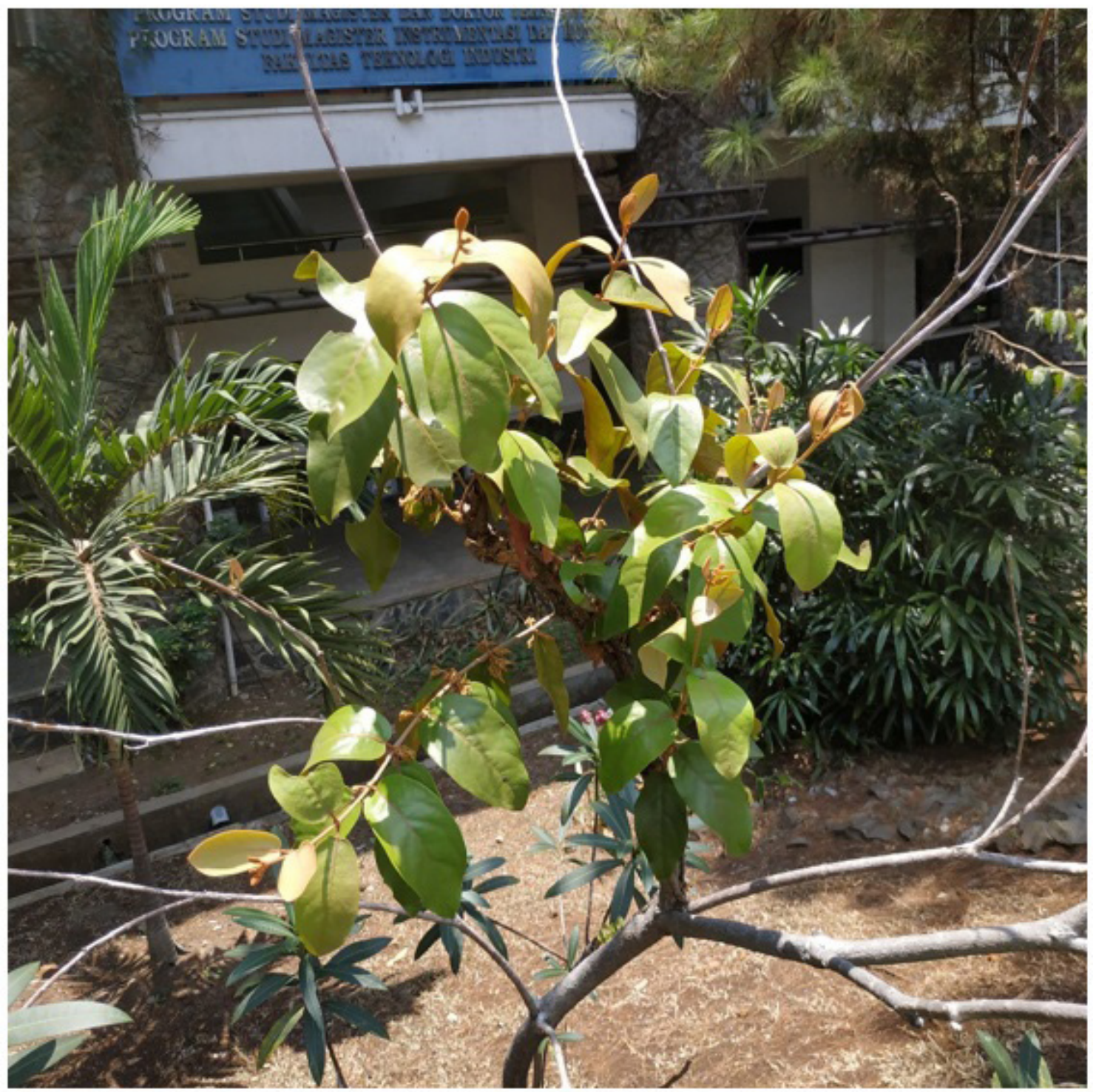

Gambar 5. S. parasitica memarasiti N. oleander di Labtek VI 
Distribus

: Indonesia (Sumatera, Jawa, Kalimantan, Bali, Nusa

Tenggara), Kamboja, India, Laos, Malaysia, Myanmar, Filipina, Thailand, dan Vietnam (Qiu and Gilbert 2003)

Habitat : Umum di hutan hujan atau hutan-hutan terbuka maupun di perkebunan dataran rendah hingga ketinggian $500 \mathrm{~m}$ dpl. (Uji et al. 2007)

Tumbuhan parasit $D$. pentandra diklasifikasikan sebagai tumbuhan parasit yang memarasiti batang (stem parasite) sekaligus tergolong hemiparasit (Guo and Ruan 2019). Pertumbuhan D. pentandra diawali dengan perkecambahan benih. Jika benih tersebut jatuh menempel pada bagian tumbuhan inang lalu kondisi sekitarnya mendukung dan sesuai untuk pertumbuhannya, maka benih tersebut akan dapat berkecambah. Bagian cabang atau ranting tumbuhan inang yang terserang $D$. pentandra akan mengalami pembengkakan (Sunaryo 1998).

Tumbuhan parasit $D$. pentandra tumbuh memarasiti inangnya melalui bantuan haustoriumnya. Haustorium dapat mengakibatkan terpotongnya aliran air dan nutrisi. Selanjutnya, tumbuhan parasit ini akan memanfaatkan air dan nutrisi tersebut untuk pertumbuhannya (Gletzel and Balasubramanian 1987). Menurut Sunaryo (1998) dampak yang ditimbulkan akibat tumbuhan parasit $D$. pentandra yaitu aliran air dan nutrisi dalam jaringan pembuluh pada tumbuhan inang tidak akan sepenuhnya mengalir rnenuju ke ujung cabang atau ranting. Tidak lancarnya aliran air dan nutrisi disebabkan adanya penghambatan oleh haustorium. Hal inilah yang mengakibatkan terjadinya penurunan pertumbuhan tumbuhan inang, terutama pada bagian yang terserang parasit. Penyebaran benih tumbuhan parasit-parasit $D$. pentandra pada umumnya dibantu oleh burungburung pemakan biji yang dari suku Dicaeidae (van Leeuwen 1954). Burung Cabai Jawa (Dicaeum trochileum) diduga menjadi agen dispersal dari tumbuhan D. pentandra di kawasan ITB Kampus Ganesha. Namun, berdasarkan hasil dari pengamatan, tidak ada dampak kerusakan yang sangat signifikan pada tumbuhan-tumbuhan inang di ITB Kampus Ganesha yang diparasiti oleh $D$. pentandra. Sunaryo (2008b) menuturkan bahwa kerusakan yang ditimbulkan oleh pemarasitan $D$. pentandra. Berdasarkan pendapat dari Sunaryo (2008b), pengendalian untuk jenis parasit $D$. pentadra dapat dilakukan dengan metode pemangkasan pada bagian cabang/ranting tumbuhan inang yang ditumbuhi oleh parasit tersebut.
Kesimpulan dari penelitian ini yaitu ditemukan sebanyak tiga jenis tumbuhan parasit yang terdapat di ITB Kampus Ganesha antara lain C. australis, $S$. parasitica, dan $D$. pentandra yang tersebar di sekitar wilayah kampus, baik bagian depan, tengah, maupun belakang. Secara keseluruhan, ketiga jenis tumbuhan parasit tersebut memarasiti delapan jenis tumbuhan inang di ITB Kampus Ganesha. Berdasarkan pemetaan, terlihat bahwa persebaran tumbuhan parasit ini terkonsentrasi di bagian tengah ITB Kampus Ganesha tepatnya di area sekitar Gedung Oktagon, Gedung TVST, Laboratorium Fisika Dasar, dan Gedung Kerjasama PLN-ITB, dengan jenis parasit $S$. parasitica dan $D$. pentandra yang kebanyakan ditemukan pada tumbuhan inang $L$. indica serta $C$. australis yang dijumpai memarasiti $A$. siamensis, E. milii, dan $L$. indica. Jenis burung Dichaeum trochileum diduga kuat menjadi agen dispersal benih untuk jenis-jenis parasit $S$. parasitica dan D. pentandra.

\section{UCAPAN TERIMA KASIH}

Terima kasih kepada Sony Saefulloh, S.T. atas bantuannya dalam proses pembuatan peta tumbuhan parasit di ITB Kampus Ganesha.

\section{DAFTAR PUSTAKA}

Backer CA, Bakhuizen Van den Brink RC. 1965. Flora of Java Vol. 2. Groningen: Noord-hoff.

Devkota NP, Kunwar RM. 2006. Pollination and dispersal of three Scurrula species (Loranthaceae) in Godawari Area of Kathmandu Valley, Nepal. J Bot Res 2:115-128.

Furuhashi T, Furuhashi, K Weckwerth W. 2011. The parasitic mechanism of the holostemparasitic plant Cuscuta. $J$ Plant Int 6:207-219.

Gletzel G, Balasubramaniam S. 1987. Mineral nutrition of mistletoe: General concepts. In: H Chr Weber and W Forstreuter (Eds.). Parasitic flowering plants. Marburg: Philipps-Universität. pp. 263-276.

Govaerts R. 1999. World Checklist of Seed Plants 3 (1, 2a, and 2b). Antwerp, Deurne: MIM.

Guo X, Ruan Z. 2019. Characterization of the complete plastome of Dendrophthoe pentandra (Loranthaceae), a stem hemiparasite. Mitochondrial DNA Part B 4:3099-3100. DOI:10.1080/23802359.2019.1667280

Heide-Jørgensen HS. 2008. Parasitic Flowering Plants. Leiden: Brill.

Irving LJ, Cameron DD. 2009. You are what you eat: interactions between root parasitic plants and their hosts. Adv Bot Res 50:87-138

Kuijt J. 1969. The Biology Of Parasitic Flowering Plants. Barkeley. Los Angeles: Univ Caliv Press.

Maarel Evd. 2005. Vegetation Ecology. New Jersey: Blackwell. Nickrent DL. 2002. Parasitic Plants of the World. Chapter 2. In: JA López-Sáez, P Catalán and L Sáez (Eds.). Parasitic Plants of the Iberian Peninsula and Balearic Islands. Madrid: Mundi-Prensa. pp. 7-22.

Nuthan D, Vasundhara M. 1997. Scrulla parasitica Linn. parasitic on Calliandra Spp. and its management. Joutnal Bombay Natural Hist Society 94:179-180. 
Pennings S, Callaway RM. 2002. Parasitic plants: parallels and contrasts with herbivores. Oecologia 131:479-489.

Pitoyo S. 1996. Benalu hortikultura: Pengendalian dan Pemanfaatan. Ungaran: Trubus Agriwidya.

Qiu H, Gilbert MG. 2003. Loranthaceae. In: Wu ZY, PH Raven, DY Hong (Eds.). In: Flora of China. Vol. 5 (Ulmaceae through Basellaceae). Beijing: Science Press. pp. 220-239.

Rhui-cheng F, Musselman LJ, Plitmann U. 1995. Cuscuta. In: Wu ZY, PH Raven (Eds.). Flora of China. Vol. 16 (Gentianaceae through Boraginaceae). Beijing: Science Press. pp. 322-325.

Rugayah, Widjaja EA, Praptiwi. 2004. Pedoman Pengumpulan Data Keanekaragaman Flora. Bogor: Pusat Penelitian Biologi-LIPI.

Sarić-Krsmanović M, Vrbničanin S. 2015. Field dodder-How to control it? Pestic Phytomed 30:137-145. DOI:10.2298/ PIF1503137S

Sholihah ARF. 2011. Daftar Spesies Burung Kampus ITB Tersedia di: https://blogs.itb.ac.id/sholihah/2011/08/24/ daftar-spesies-burung-kampus-itb/ [Tanggal diakses: 24 Februari 2020]

Sunaryo 1998. Identifikasi kerusakan-kerusakan tumbuhan inang oleh parasit Dendrophthoe pentandra (L.) Miq. (Loranthaceae): Sebuah studi kasus di Tahura Bengkulu. Berita Biologi 4:80-85.

Sunaryo. 2003. Sebuah tinjauan tentang parasit Taliputri (Cuscuta spp.) dan Pengendaliannya. Berita Biologi 6:793-800.
Sunaryo. 2008a. Preferensi dan kerusakan tumbuhan koleksi Kebun Raya Cibodas oleh benalu Scurrula oortiana (Korth.) Dans Berk Penel Hayati 14:45-53.

Sunaryo. 2008b, Pemarasitan benalu Dendrophthoe pentandra (L.) Miq. pada tanaman koleksi Kebun Raya Cibodas, Jawa Barat. Jurnal Natur Indonesia 11:48-58.

Thriveni MC, Shivamurthy GR, Amruthesh KN, Vijay CR, Kavitha GR. 2010. Mistletoe and their hosts in Karnataka. $J$ American Sci 6:827-835.

Twyford AD. 2018. Parasitic plants. Current biology magazine 28:857-859. DOI:10.1016/j.cub.2018.06.030

Uji T, Sunaryo, Rachman E. 2007. Keanekaragaman jenis benalu parasit pada koleksi di Kebun Raya Eka Karya, Bali. Berk Penel Hayati 13:1-5.

Van Leeuwen WM. 1954. On the biology of some Javanese Loranthaceae and the role birds play in their life history. Beaufortia 4:103-207

Wardini TH, Kusdianti. 2005. Perkembangan haustorium Cuscuta australis. In: Seminar Nasional Penggalang Tkasonomi Tumbuhan Indonesia. Bandung: Universitas Pendidikan Indonesia.

Yu H, Liu J, He W, Miao S, Dong M. 2011. Cuscuta australis restrains three exotic invasive plants and benefits native species. Biol Invasions 13:747-756. 